\title{
Erratum: Molecular and cellular signatures underlying superior immunity against Bordetella pertussis upon pulmonary vaccination
}

RHM Raeven, J Brummelman, JLA Pennings, L van der Maas, K Helm, W Tilstra, A van der Ark, A Sloots, $P$ van der Ley, W van Eden, W Jiskoot, E van Riet, CACM van Els, GFA Kersten, WGH Han and B Metz

Mucosal Immunology (2018) 11: 1009; doi:10.1038/mi.2017.110; published online 7 February 2018

Correction to: Mucosal Immunology advance online publication, 20 September 2017; doi: 10.1038/mi.2017.81

This article was originally published under NPG's License to Publish, but has now been made available under a CC BY 4.0 license. The PDF and HTML versions of the paper have been modified accordingly.

(c) (i)

This work is licensed under a Creative Commons Attribution 4.0 International License. The images or other third party materialin thisarticleareincluded in thearticle's Creative Commonslicense, unlessindicated otherwise in the creditline; if the material is not included under the Creative Commons license, users will need to obtain permission from the license holder to reproduce the material. To view a copy of this license, visit http://creativecommons.org/licenses/by/4.0/

(C) The Author(s) 2018 